\title{
PI3K Inhibitor BGT226
}

National Cancer Institute

\section{Source}

National Cancer Institute. PI3K Inhibitor BGT226. NCI Thesaurus. Code C74073.

A phosphatidylinositol 3-kinase (PI3K) inhibitor with potential antineoplastic activity. PI3K inhibitor BGT 226 specifically inhibits PI3K in the PI3K/AKT kinase (or protein kinase B) signaling pathway, which may trigger the translocation of cytosolic Bax to the mitochondrial outer membrane, increasing mitochondrial membrane permeability; apoptotic cell death may ensue. Bax is a member of the proapoptotic Bcl2 family of proteins. 